\title{
Criminal-Legal Limits of Medical Intervention in Relation to a Healthy Person
}

\section{Sumachev AV*}

Doctor of law, Professor of Criminal Law and Criminal Procedure, Ugra State University, Russia

*Corresponding author: Alexey Vitalyevich Sumachev, Doctor of law, Professor of Criminal Law and Criminal Procedure, Ugra State University, 628012, Khanty-Mansiysk, Russia, Tel: 8-922-478-71-22; Email: alekssumachev@mail.ru

\section{Commentary}

Volume 5 Issue 2

Received Date: March 31, 2022

Published Date: April 18, 2022

DOI: $10.23880 /$ abca-16000226

\section{Abstract}

There is no doubt that in modern society it is necessary to adequately correlate the achievements of science and the basic values of a person, first of all, his life and health. In this regard, a detailed definition of the criminal-legal limits of medical intervention in relation to a healthy person should be determined not only at the level of medical rules, but also in the relevant, including repressive, legislation. The article specifies the forms of medical intervention in relation to a healthy person and further examines the criminal legal limits of the implementation of appropriate medical manipulations.

Keywords: Medical Intervention; Diagnostics; Surgery; Donation; Sterilization; Termination of Pregnancy

\section{Introduction}

Initially, we note that medical intervention in relation to a healthy person can be expressed in the following forms:

- Diagnostic medical examination (for example, conducting preliminary and/or periodic medical examinations (examinations));

- Preventive medical activities (for example, vaccination of the population against the COVID-19 coronavirus);

- Implementation of medical research (for example, testing of medical products (medicines) on volunteers medical experiments);

- Plastic surgery (surgery that deals with surgical interventions aimed at eliminating deformations and defects of any organ, tissue or surface of the human body [1]);

- Gender reassignment surgery [see, for example: [2];

- Lifetime donation of human organs and tissues and their transplantation (transplantation);

- Donation of blood and (or) its components;

- The use of assisted reproductive technologies (ART) in the treatment of female and male infertility;
- Medical sterilization;

- Artificial termination of pregnancy.

There is no doubt that when performing medical intervention in relation to a healthy person, not only organizational and medical, but also legal requirements must be observed. Among the legal requirements, the criminal legal limits of medical intervention in relation to a healthy person are of particular importance, since such intervention, on the one hand, can cause harm to human health or even cause his death, on the other hand, certain forms of medical intervention (for example, lifetime organ donation for transplantation, medical sterilization or artificial termination of pregnancy) are similar in consequences to the facts of criminal harm to health. Accordingly, the detailed development of the criminal-legal limits of medical intervention in relation to a healthy person is an urgent task.

\section{Materials and Methods}

The main source for writing this article is the current Criminal Code of the Russian Federation, the Criminal Code 
of Spain, as well as materials of monographic research and journal publications.

In the course of the research, the main methods of cognition were used: problem-chronological, systemic and comparative jurisprudence. The author's reasoning is based on a problem-chronological approach. The application of the system method made it possible to integrate the achievements of various fields of knowledge (criminal law, philosophy, morality, religion, psychology, medicine) into the criminal law doctrine and formulate conclusions on the problems posed in the article.

So, let's consider some forms of medical intervention in relation to a healthy person.

The legal regulation of the use of assisted reproductive technologies (ART) in the treatment of female and male infertility in the most general form is carried out on the basis of Article 55 of the Federal Law "On the Basics of protecting the health of citizens in the Russian Federation" dated November 21, 2011 No. 323-FZ [3] (hereinafter referred to as the Law), and in more detail - "Instructions for the use of methods of assisted reproductive technologies" approved by the Order of the Ministry of Health of the Russian Federation "On the use of assisted reproductive technologies (ART) in the treatment of female and male infertility" dated February 26, 2003 No. 67 [4]. According to the Law, "a man and a woman, both married and unmarried, have the right to use assisted reproductive technologies in the presence of mutual informed voluntary consent to medical intervention. A single woman also has the right to use assisted reproductive technologies if she has informed voluntary consent to medical intervention" (Part 3 of Article 55 of the Law). Further in this article, the conditions for the use of assisted reproductive technologies are specified. It is worth noting that earlier, namely in art. 35 "Fundamentals of the Legislation of the Russian Federation on the protection of citizens' health", approved by the Supreme Council of the Russian Federation on July 22, 1993 No. 5487-1 [5], it was noted that "illegal artificial insemination and embryo implantation entails criminal liability established by the legislation of the Russian Federation." It is worth noting that the criminal legislation of Russia did not and does not provide for a special rule establishing responsibility for such acts (unlike, for example, Article 162 of the Spanish Criminal Code [6]). If, as a result of artificial insemination or embryo implantation, harm is caused to a woman's health, the act should be regarded as a careless crime (respectively, Article 109 or Article 118 of the Criminal Code of the Russian Federation (hereinafter - the Criminal Code of the Russian Federation)).

The institute for the protection of the rights of a pregnant woman seems to be sufficiently developed at the level of criminal legislation. It can be indicated, for example, that the state of pregnancy affects the imposition of punishment (paragraph "c" of Part 1 of Article 61 of the Criminal Code), exemption from punishment (Article 82 of the Criminal Code), the qualification of the act (paragraph " $d$ " of Part 2 of Article 105, Article 111, 118, Article 123, paragraph "e" of Part 2 of Article 126, Article 145 of the Criminal Code, etc.). Criminal legal consequences in most of these cases are not related to the subjective attitudes (desires) of a woman, but are related to the very fact of pregnancy. In this case, it is necessary to consider the legal consequences caused by the will of a pregnant woman, and, in particular, her consent to an artificial termination of pregnancy. The conditions for the legality of artificial termination of pregnancy are defined in Article 56 of the Law, where, first of all, it is noted: "Every woman independently decides the issue of motherhood. Artificial termination of pregnancy is carried out at the request of a woman with informed voluntary consent." Further, the grounds and procedure for artificial termination of pregnancy are specified, that is, the conditions for the legality of medical intervention of this type. Here, in Part 8 of Article 56 of the Law, it is stated: "Illegal artificial termination of pregnancy entails criminal liability established by the legislation of the Russian Federation."

Criminal legislation also operates with such a feature as the production of an abortion by a person who does not have a higher medical education of the appropriate profile (Article 123 of the Criminal Code of the Russian Federation). Thus, the conditions for the legality of methods of artificial termination of pregnancy should be correlated: with the term of pregnancy (medical and social indicator); the consent of the woman (legal indicator) and the availability of higher medical education of the appropriate profile (criminal law indicator).

The conditions for the legality of medical sterilization are determined only at the level of medical legislation. In the most general terms, these rules are established by Article 57 of the Law: "Medical sterilization as a special medical intervention in order to deprive a person of the ability to reproduce offspring or as a method of contraception can be carried out only upon a written application of a citizen (our italics.-A.S) over the age of thirty-five or a citizen with at least two children, and in the presence of medical indications and informed voluntary consent of a citizen - regardless of age and the presence of children. Thus, the conditions for the legality of medical sterilization as a method of permanent infliction of serious harm to health have a socio-medical and legal nature: medical indicators of the permissibility of sterilization, social (age, presence of children, etc.) and legal - the consent of a person to sterilization. It is logical to consider the issue of donation of human organs and tissues and their transplantation (transplantation) in parallel with 
the problem of blood donation and (or) its components. Moreover, in the legal literature they are also considered in interrelation [7-9].

As criteria for the legality of blood donation and, especially, transplantation of human organs and tissues, I.I. Gorelik and somewhat later A.N. Krasikov identified the following:

- The patient cannot be assisted by any means other than organ and tissue transplantation;

- The harm caused to the donor is less than the prevented harm to the recipient patient. And then they noticed that transplantation would not be legitimate in the absence of at least one of these conditions $[8,9]$.

Such close attention of lawyers to this problem was due, on the one hand, to the fact that such methods of treatment at that time (the 80s of the XX century) were in the process of formation, and, on the other hand, to the absence at that time of a detailed developed relevant legislation. Thus, almost the only normative act regulating donation issues at that time was the resolution of the RSFSR Council of People's Commissars "On donor personnel" dated April 22, 1935 [10].

Modern medical and legal practice has developed a number of conditions under which the actions of doctors in the donation of human organs and tissues and their transplantation (transplantation), as well as blood and (or) its components should be recognized as legitimate. In particular, the conditions for the legality of donation of human organs and tissues and their transplantation (transplantation), as well as blood and (or) its components, logically follow from the provisions of the Law of the Russian Federation "On Transplantation of Human Organs and (or) tissues" of December 22, 1992 No. 4180-1 [11], art. 47 of the Federal Law "On the Basics of Public Health Protection in the Russian Federation" dated November 21, 2011 No. 323-FZ, Federal Law of the Russian Federation "On Blood Donation and its Components" dated July 20, 2012 No. 125-FZ [12]. These include:

- A living donor freely and consciously consented to the removal of his organs and (or) tissues or to the donation of blood and (or) its components;

- The removal of organs and (or) tissues from a donor or the taking of blood and (or) its components from a donor is permissible only if the donor's health is not harmed;

- Human organs and (or) tissues cannot be the subject of purchase and sale, and the sale of donated blood and (or) its components obtained within the territory of the Russian Federation to other states is prohibited;

- The donor has undergone a comprehensive medical examination and there is a conclusion of a council of medical specialists on the possibility of removing organs and (or) tissues from him for transplantation, or the donor has no medical contraindications for donating blood and (or) its components.

Foreign legal practice, and, in particular, the Spanish Criminal Code, defines the inviolability of actions in organ transplantation in the presence of a free agreement on this and compliance with the act of transplantation with the law, if the agreement was not falsified, received for a fee or the consenting person was a minor or incapacitated (Article 156 of the Spanish Criminal Code) [6]. It can be noted that the conditions of the impossibility of harming the health of the donor during transplantation in Russia and Spain largely coincide. Nevertheless, it is necessary to recognize the positive experience of the Spanish legislator, who defined such criteria at the level of criminal law.

Based on the provisions of Russian legislation, it can be concluded that violation of any of the above conditions for the legality of donation of human organs and tissues and their transplantation (transplantation), as well as blood and (or) its components, should entail legal, including criminal, liability.

\section{Results}

These are the main criminal-legal limits of medical intervention in relation to a healthy person, established by the legislation of Russia. Knowledge of them is appropriate not only for medical professionals, but also for healthy patients who have expressed a desire to carry out appropriate medical procedures.

\section{References}

1. (2021) Wikipedia is a free encyclopedia [Electronic resource].

2. (2021) Order on the replacement of the diploma of Candidate of Sciences dated July 18, 2019 No. 685/nc Higher Attestation Commission under the Ministry of Science and Higher Education of the Russian Federation.

3. (2011) Collection of legislation of the Russian Federation 48: 6724.

4. (2003) Rossiyskaya Gazeta.

5. (1993) Vedomosti of the Congress of People's Deputies and the Supreme Soviet of the Russian Federation 33: 1318.

6. Kuznetsova NF, Reshetnikova FM (1998) The Spanish Criminal Code. Publishing House of ZERTSALO, pp: 218.

7. Avdeev MI (1968) Legal regulation of organ and tissue 
transplantation. Soviet state and law 9: 83-88.

8. Gorelik II (1971) Legal aspects of organ and tissue transplantation. Minsk, pp: 91.

9. Krasikov AN (1976) The essence and meaning of the victim's consent in Soviet criminal law; Edited by Prof. I.S. Nov. Saratov: Sarat Publishing House, pp: 121.
10. (1935) Collection of laws and regulations of the Workers' and Peasants' government 13.

11. (1993) Vedomosti of the Congress of People's Deputies and the Supreme Soviet of the Russian Federation 2: 62 .

12. (2012) Rossiyskaya Gazeta.

(c) (1) 